\title{
PENGARUH REgULASI PEMERINTAH, PROFITABILITAS, LEVERAGE, KEPEMILIKAN INSTITUSIONAL, DAN KEPEMILIKAN ASING TERHADAP PENGUNGKAPAN CORPORATE SOCIAL RESPONSIBILITY
}

(Studi Empiris Perusahaan Manufaktur Yang Terdaftar Di Busa Efek Tahun 2013-2016)

\author{
Carolina Christanti Nopando ${ }^{1}$, Diah Ayu Susanti ${ }^{2}$
}

Program Studi Akuntansi Fakultas Ekonomi dan Bisnis Universitas Muria Kudus

Icarolina120796@gmail.com

2 diah.ayususanti3@gmail.com

\begin{abstract}
ABSTRAK
Penelitian ini bertujuan untuk menguji pengaruh regulasi pemerintah, profitabilitas, leverage, kepemilikan institusional, dan kepemilikan asing. Data penelitian yang digunakan adalah data sekunder berupa laporan tahunan perusahaan manufaktur yang terdaftar di Bursa Efek Indonesia Tahun 2013-2016. Metode pengambilan sampel yang digunakan adalah metode purposive sampling. Banyaknya sampel yang digunakan dalam penelitian ini adalah 84 perusahaan. Teknik analisis data yang digunakan adalah analisis regresi linier berganda. Hasil penelitian ini menunjukkan bahwa profitabilitas, leverage, kepemilikan institusional berpengaruh positif terhadap pengungkapan corporate social responsiobility, sedangkan regulasi pemerintah dan kepemilikan asing tidak berpengaruh terhadap pengungkapan corporate social responsibility.
\end{abstract}

Kata kunci: Profitabilitas, Leverage, Kepemilikan Institusional, dan Pengungkapan Corporate Social Responsibility.

\section{ABSTRACT}

This research is aimed to examine the influence of the government regulations, the profitabilities, leverage, institutional ownership and foreign ownership. The research data that was used is the secondary data in form of an annual report of the manufactory companies which are listed in Indonesia Stock Exchange in 2013-2016. The method of taking a sample that was used is purposive sampling. The sample total that was used in this research are 84 companies. The technique of analyzing the data that was used is multiple linear regression analysis. The result of this research shows that the profitabilities, leverage, institutional ownership positively influence corporate social responsibility disclosure, while the government regulations and foreign ownership do not have any influences towards corporate social responsibility disclosure.

Key words: Profitabilities, Leverage, Institutional Ownership, and Corporate Social Responsibility Disclosure.

\section{PENDAHULUAN}

Perusahaan sebagai salah satu pelaku ekonomi mempunyai peranan yang sangat penting terhadap keberlangsungan hidup perekonomian dan masyarakat luas dalam menghadapi era globalisasi sekarang ini. Kemajuan di bidang informasi dan teknologi serta adanya keterbukaan pasar menjadikan perusahaan-perusahaan yang ada harus memperhatikan 
secara serius dan terbuka mengenai dampak dari tingkah laku perusahaan itu sendiri terhadap lingkungan dan stakeholders.

Lingkungan pada saat ini telah menjadi isu penting yang berkembang di masyarakat. Keberlangsungan lingkungan menjadi hal yang disorot banyak pihak akibat seringkali mengabaikan kondisi lingkungan perusahaan. Lingkungan bagi perusahaan juga memiliki pengaruh yang penting, tidak hanya bagi lingkungan intern perusahaan namun juga lingkungan ekstern perusahaan. Salah satu bentuk pertanggungjawaban sosial dan lingkungan yang dilakukan oleh perusahaan adalah melalui pengungkapan Corporate Social Responsibility (CSR).

Sejak tahun 1971, Freeport Indonesia masuk ke daerah keramat yaitu daerah Amungsal (Tanah Amungme). Daerah tersebut dianggap keramat oleh masyarakat setempat, sehingga secara adat tidak di ijinkan untuk dimasuki. Meskipun demikian Freeport tetap membuka tambang baru yang di beri nama tambang Erstberg. Sejak tahun 1971 itulah warga suku Amuge dipindahkan keluar dari wilayah mereka kewilayah kaki pegunungan. Dari pemindahan tersebut suku Amungme tidak setuju dan melakukan perlawanan, akan tetapi apalah daya masyarakat kecil yang tidak memiliki dukungan dari legitimasi aparat keamanan, maka berujung pada pemindahan di sekitar wilayah kaki gunung tersebut secara paksa (Hadi, 2011:3).

Setelah tambang Erstberg, habis open-pitnya pada tahun 1989, dilanjutkan dengan penambangan pada wilayah Grasberg dengan izin produksi yang dikeluarkan pada tahun 1996. Dalam izin tersebut, tercantum dalam AMDAL bahwa izin produksi yang diperkenankan sebesar 300 ribu/ton/hari. Namun kenyataanya adalah terjadi ekploitasi tanpa batas, kurang berpihak pada alam dan masyarakat (Hadi, 2011:4).

\section{TINJAUAN PUSATAKA}

\section{Teori Sinyal}

Teori sinyal menyatakan bahwa terdapat kandungan informasi pada pengungkapan suatu informasi yang dapat menjadi sinyal bagi investor dan pihak potensial lainnya dalam pengambilan keputusan (Jogiyanto, 2003). Informasi yang dipublikasikan sebagai suatu pengumuman yang akan diterima investor sebagai sinyal dalam pengambilan keputusan investasinnya. Investor akan terlebih dahulu menganalisis dan menginterpretasikan 
pengumuman tersebut sebagai sinyal baik ataupun sinyal yang buruk. Jika pengumuman yang di terima tersebut merupakan sinyal baik, maka diharapkan pasar akan bereaksi pada waktu pengumuman tersebut diterima oleh pasar.

\section{Kerangka Pikir}

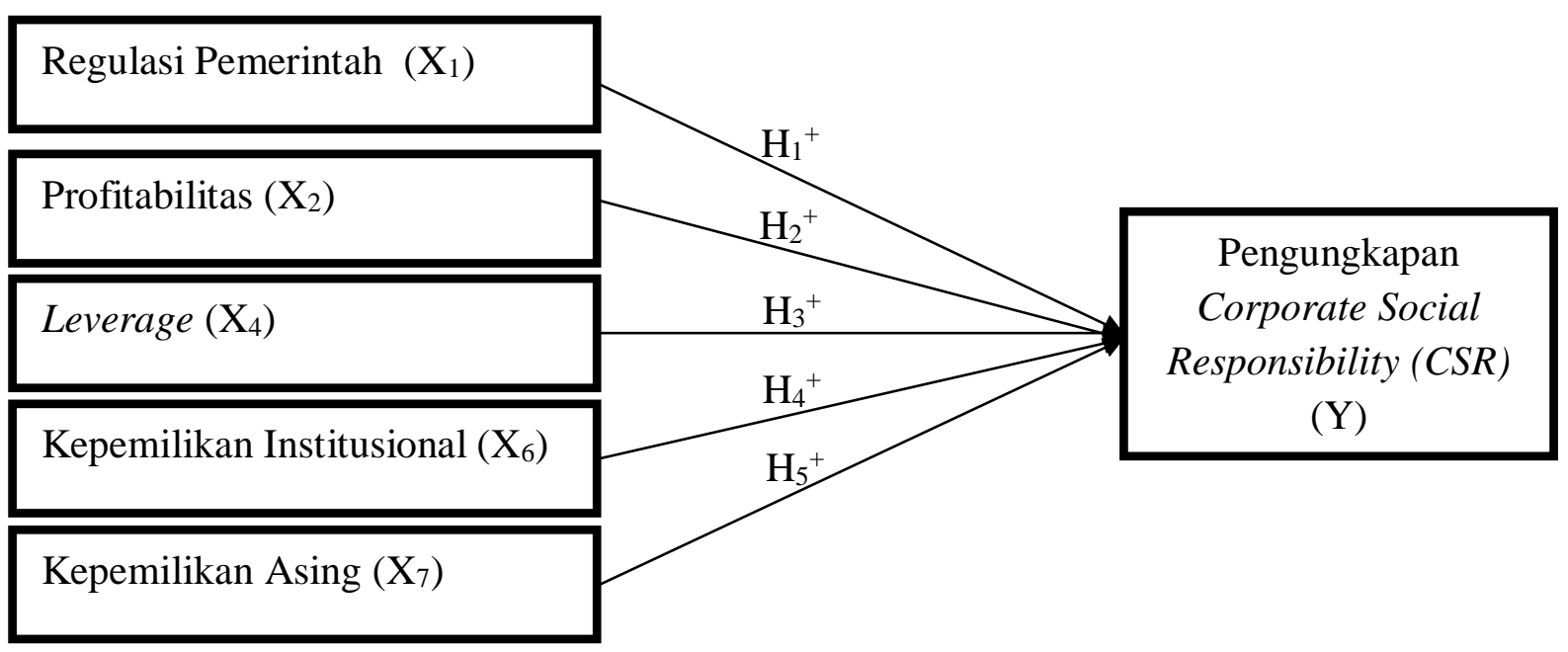

\section{METODE PENELITIAN}

Penelitian ini menggunakan data sekunder yang mengacu pada data laporan keuangan yang diperoleh dari Bursa Efek Indonesia. Populasi dalam penelitian ini adalah perusahaan manufaktur yang terdaftar di Bursa Efek Indonesia tahun 2013-2016. Teknik pengambilan sampel adalah purposive sampling dan teknik analisis yang digunakan yaitu regresi liniear berganda. Sampel yang akan diteliti berjumlah 84 perusahaan.

\section{Pengukuran Variabel}

\section{Regulasi Pemerintah}

Regulasi pemerintah adalah segala peraturan yang dikeluarkan pemerintah untuk mengatur perusahaan.

$$
\text { Regulasi Pemerintah = Logaritma Natural (Beban Pajak) }
$$

\section{Profitabilitas}

Profitabilitas merupakan kemampuan perusahaan untuk memperoleh laba dalam rangka untuk meningkatkan nilai stakeholder (pemegang saham). Rasio merupakan skala yang akan digunakan untuk pengukuran profitabilitas perusahaan. 


$$
\mathrm{ROA}=\frac{\text { Laba Bersih }}{\text { Total asset }}
$$

\section{Leverage}

Leverage dapat diartikan sebagai alat ukur tingkat ketergantungan perusahaan terhadap utang dalam membiayai kegiatan operasinya, dengan demikian leverage juga mencerminkan tingkat resiko keuangan.

$$
\text { Leverage }=\frac{\text { Total Utang }}{\text { Total Ekuitas }}
$$

\section{Kepemilikan Institusional}

Kepemilikan Institusional merupakan kepemilikan saham yang dimiliki oleh investor institusional.

$$
\text { Kep. Institusio nal }=\frac{\text { Jumlah kepemilika } \mathrm{n} \text { saham oleh pihak institusio nal }}{\text { Jumlah saham yang beredar }}
$$

\section{Kepemilikan Asing}

Kepemilikan asing adalah prosentase jumlah saham yang dimiliki pihak asing dari seluruh modal saham perusahaan.

$$
\text { Kepemilika } n \text { Asing }=\frac{\text { Kepemilkan Asing }}{\sum \text { Saham yang diterbitka } n}
$$

\section{HASIL DAN PEMBAHASAN}

\section{Hasil Uji Statistik Deskriptif}

Ringkasan hasil statistik deskriptif disajikan sebagai berikut:

\begin{tabular}{|l|c|r|r|r|r|}
\hline & $\mathrm{N}$ & Minimum & Maximum & Mean & Std. Deviation \\
\hline Regulasi Pemerintah & 84 & 20.10 & 29.41 & 26.0801 & 2.33360 \\
Profitabilitas & 84 & .01 & .40 & .1412 & .09179 \\
Leverage & 84 & .07 & 1.99 & .6805 & .47802 \\
Kepemilikan Institusional & 84 & .02 & .76 & .2467 & .14266 \\
Kepemilikan Asing & 84 & .01 & .74 & .3465 & .13832 \\
Corporate Social & & .50 & .67 & .5711 & .04344 \\
Responsibility & 84 & & & & \\
Valid N (listwise) & & & & & \\
\hline
\end{tabular}




\section{Hasil Uji Asumsi Klasik}

\section{Uji Normalitas}

\section{Hasil Uji Kolmogorov smirnov}

\begin{tabular}{|ll|r|}
\hline & & Unstandardized Residual \\
\hline $\mathrm{N}$ & & 84 \\
Normal Parameters $^{\mathrm{a}, \mathrm{b}}$ & Mean &, 0000000 \\
& Std. Deviation & .03073309 \\
Most Extreme Differences & Absolute & .071 \\
& Positive & .055 \\
& Negative & -.071 \\
Test Statistic & & .071 \\
Asymp. Sig. (2-tailed) & &, $200^{\mathrm{c}, \mathrm{d}}$ \\
\hline
\end{tabular}

Berdasarkan hasil pada tabel diatas, diketahui bahwa nilai signifikan dari kolmogorovsmirnov sebesar 0,200. Nilai ini lebih besar dari 0,05 sehingga data terdistribusi normal atau memenuhi asumsi klasik normalitas residual, dengan demikian asumsi normalitas terpenuhi.

\section{Uji Multikolonieritas}

\section{Hasil Uji Multikolonieritas}

\begin{tabular}{|l|c|c|}
\hline \multirow{2}{*}{\multicolumn{1}{|c|}{ Variabel }} & \multicolumn{2}{c|}{ Collinearity Statistics } \\
\cline { 2 - 3 } & Tolerance & VIF \\
\hline Regulasi Pemerintah & 0,631 & 1,585 \\
\hline Profitabilitas & 0,779 & 1,283 \\
\hline Leverage & 0,779 & 1,284 \\
\hline Kepemilikan Institusional & 0,799 & 1,252 \\
\hline Kepemilikan Asing & 0,875 & 1,143 \\
\hline
\end{tabular}

Dari tabel diatas menunjukan bahwa semua variabel memiliki nilai tolerance lebih dari 0,10 dan memiliki nilai VIF kurang dari 10. Jadi dapat disimpulkan tidak terjadi multikolonieritas antar variabel bebas dalam model regresi, sehingga uji multikolonieritas terpenuhi 


\section{Uji Heteroskedastisitas}

\section{Hasil Uji Glejser}

\begin{tabular}{|c|c|c|c|c|c|c|}
\hline \multirow[b]{2}{*}{ Mod } & & \multicolumn{2}{|c|}{$\begin{array}{c}\text { Unstandardized } \\
\text { Coefficients }\end{array}$} & \multirow{2}{*}{$\begin{array}{c}\begin{array}{c}\text { Standardized } \\
\text { Coefficients }\end{array} \\
\text { Beta }\end{array}$} & \multirow[b]{2}{*}{$\mathrm{T}$} & \multirow[b]{2}{*}{ Sig. } \\
\hline & & $\mathrm{B}$ & Std. Error & & & \\
\hline \multirow[t]{6}{*}{1} & (Constant) & -.022 & .024 & & -.933 & .354 \\
\hline & Regulasi Pemerintah & .002 & .001 & .257 & 1.888 & .063 \\
\hline & Profitabilitas & -.034 & .022 & -.187 & -1.527 & .131 \\
\hline & Leverage & -.006 & .004 & -.170 & -1.382 & .171 \\
\hline & Kepemilikan Institusional & -.002 & .014 & -.013 & -.106 & .916 \\
\hline & Kepemilikan Asing & .026 & .014 & .212 & 1.834 & .070 \\
\hline
\end{tabular}

Hasil output diatas menyatakan bahwa semaua nilai signifikan variabel independen lebih besar dari 0,05 artinya variabel independen tidak ada yang signifikan, maka dapat disimpulkan bahwa model regresi tidak terdapat heteroskedastisitas, dengan demikian uji heteroskedastisitas terpenuhi.

\section{Uji Autokorelasi}

Uji Run Test

\begin{tabular}{|l|r|}
\hline & $\begin{array}{c}\text { Unstandardized } \\
\text { Residual }\end{array}$ \\
\hline Test Value $^{\mathrm{a}}$ & -.00183 \\
Cases $<$ Test Value & 42 \\
Cases $>=$ Test Value & 42 \\
Total Cases & 84 \\
Number of Runs & 46 \\
Z & .659 \\
Asymp. Sig. (2-tailed) & .510 \\
\hline
\end{tabular}

Hasil uji run test menunjukkan bahwa nilai Signifikan adalah 0,510>0,05 yang berarti hipotesis nol diterima. Dengan demikian, data yang dipergunakan acak sehingga tidak terdapat masalah autokorelasi pada data yang diuji, dengan demikian autokorelasiterpenuhi. 


\section{Analisis Regresi Linier Berganda}

Hasil Analisis Regresi Liniear Berganda

\begin{tabular}{|c|c|c|c|c|c|c|}
\hline \multirow[b]{2}{*}{ Mode } & & \multicolumn{2}{|c|}{$\begin{array}{c}\text { Unstandardized } \\
\text { Coefficients }\end{array}$} & \multirow{2}{*}{$\begin{array}{c}\begin{array}{c}\text { Standardized } \\
\text { Coefficients }\end{array} \\
\text { Beta }\end{array}$} & \multirow[b]{2}{*}{$\mathrm{T}$} & \multirow[b]{2}{*}{ Sig. } \\
\hline & & $\mathrm{B}$ & Std. Error & & & \\
\hline \multirow[t]{6}{*}{1} & (Constant) & .443 & .046 & & 9.745 & .000 \\
\hline & Regulasi Pemerintah & .002 & .002 & .122 & 1.212 & .229 \\
\hline & Profitabilitas & .108 & .043 & .228 & 2.513 & .014 \\
\hline & Leverage & .035 & .008 & .385 & 4.237 & .000 \\
\hline & Kepemilikan Institusional & .067 & .027 & .221 & 2.465 & .016 \\
\hline & Kepemilikan Asing & .037 & .027 & .117 & 1.365 & .176 \\
\hline
\end{tabular}

Berdasarkan hasil perhitungan regresi yang telah diperoleh, maka dapat dibentuk persamaan regresi liniear berganda sebagai berikut:

$$
Y=0,443+0,002 X_{1}+0,108 X_{2}-0,035 X_{3}+0,067 X_{4}+0,037 X_{5}+e
$$

Berdasarkan persamaan diatas dapat dilakukan interprestasi sebagai berikut:

1. Regulasi pemerintah memiliki koefisien bertanda positif sebesar 0,002 artinya peningkatan regulasi pemerintah dalam kelipatan eksponensial diprediksi akan meningkatkan pengungkapan corporate social responsibility sebesar 0,2\%.

2. Profitabilitas memiliki koefisien bertanda positif sebesar 0,108 artinya peningkatan profitabilitas dalam kelipatan eksponensial diprediksi akan meningkatkan pengungkapan corporate social responsibility sebesar 10,8\%.

3. Leverage memiliki koefisien bertanda positif sebesar 0,035 artinya peningkatan leverage dalam kelipatan eksponensial diprediksi akan meningkatkan pengungkapan corporate social responsibility sebesar 3,5\%. 
4. Kepemilikan institusional memiliki koefisien bertanda positif sebesar 0,067 artinya kepemilikan institusional pemerintah dalam kelipatan eksponensial diprediksi akan meningkatkan pengungkapan corporate social responsibility sebesar 6,7\%.

5. Kepemilikan asing memiliki koefisien bertanda positif sebesar 0,037 artinya peningkatan kepemilikan asing dalam kelipatan eksponensial diprediksi akan meningkatkan pengungkapan corporate social responsibility sebesar 3,7\%.

\section{Pengujian Hipotesis}

\section{Koefisien Determinasi $\left(\mathbf{R}^{2}\right)$}

Tabel 4.7

Hasil Analisis Koefisien Determinasi $\left(\mathbf{R}^{2}\right)$

\begin{tabular}{|l|r|r|r|r|}
\hline Model & \multicolumn{1}{|c|}{$\mathrm{R}$} & R Square & \multicolumn{1}{|c|}{$\begin{array}{c}\text { Adjusted } \mathrm{R} \\
\text { Square }\end{array}$} & $\begin{array}{l}\text { Std. Error of the } \\
\text { Estimate }\end{array}$ \\
\hline 1 &, $707^{\mathrm{a}}$ &, 499 &, 467 &, 03170 \\
\hline
\end{tabular}

Berdasarkan tabel 4.7 diatas dapat dilihat bahwa nilai koefisien korelasi berganda (R) sebesar 0,707 menunjukkan bahwa regulasi pemerintah, profitabilitas, ,leverage, kepemilikan institusional, kepemilikan asing memiliki hubungan dengan corporate social responsibility pada perusahaan manufaktur. Nilai koefisien determinasi (adjusted RSquare) sebesar 0,467 menunjukkan bahwa regulasi pemerintah, profitabilitas,leverage, kepemilikan institusional, kepemilikan asing secara simultan memberikan pengaruh sebesar $46,7 \%$ terhadap corporate social resposibility pada perusahaan manufakturyang terdaftar di Busa Efek Indonesia periode 2013-2016, sedangkan sisanya 53,3\% merupakan pengaruh faktor-faktor lain diluar variabel penelitian.

\section{Uji Simultan (Uji F)}

\section{Hasil Analisis Uji F}




\begin{tabular}{|ll|r|r|r|c|c|}
\hline \multicolumn{2}{|l|}{} & & & Mean & & \\
\hline 1 & Sudel of Squares & $\mathrm{df}$ & Square & F & Sig. \\
\hline & Regression & .078 & 5 & .016 & 15.563 & $.000^{\mathrm{b}}$ \\
& Residual & .078 & 78 & .001 & & \\
& Total & .157 & 83 & & & \\
\hline
\end{tabular}

Berdasarkan tabel diatas menunjukkan $\mathrm{F}$ hitung 15,563 sedangkan pada $\mathrm{F}$ tabel tingkat kepercayaan 95\% $(\mathrm{a}=0,05)$ adalah 2,33. Hal ini berarti $\mathrm{F}$ hitung $>$ Ftabel $(11,145>2,33)$ dengan tingkat signifikan 0,000 yang lebih kecil dari $\alpha(0,05)$ sehingga seluruh variabel independen tersebut berpengaruh secara bersama-sama terhadap corporate social responsibility. Hal ini menunjukkan bahwa regulasi pemerintah, profitabilitas,leverage, kepemilikan institusional, kepemilikan asing secara simultan berpengaruh terhadap corporate social responsibility.

\section{Uji Parsial (Uji t)}

\section{Hasil Analisis Uji t}

\begin{tabular}{|c|c|c|c|c|c|c|}
\hline \multirow[b]{2}{*}{ Mod } & & \multicolumn{2}{|c|}{$\begin{array}{c}\text { Unstandardized } \\
\text { Coefficients } \\
\end{array}$} & \multirow{2}{*}{ 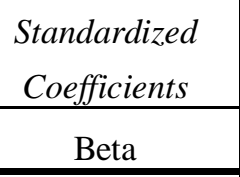 } & \multirow[b]{2}{*}{$\mathrm{T}$} & \multirow[b]{2}{*}{ Sig. } \\
\hline & & $\mathrm{B}$ & Std. Error & & & \\
\hline \multirow[t]{6}{*}{1} & (Constant) & .443 & .046 & & 9.745 & .000 \\
\hline & Regulasi Pemerintah & .002 & .002 & .122 & 1.212 & .229 \\
\hline & Profitabilitas & .108 & .043 & .228 & 2.513 & .014 \\
\hline & Leverage & .035 & .008 & .385 & 4.237 & .000 \\
\hline & Kepemilikan Institusional & .067 & .027 & .221 & 2.465 & .016 \\
\hline & Kepemilikan Asing & .037 & .027 & .117 & 1.365 & .176 \\
\hline
\end{tabular}

Berdasarkan tabel di atas dapat dijelaskan sebagai berikut:

\section{Pengaruh Regulasi Pemerintah terhadap Corporate Social Responsibility}

Berdasarkan tabel diatas diketahui bahwa variabel regulasi pemerintah memiliki nilai $\mathrm{t}_{\text {hitung }}<\mathrm{t}_{\text {tabel }}(1,212<1,99085)$ dan nilai sig sebesar $0,229>0,05$ berarti variabel regulasi pemerintah tidak berpengaruh terhadap corporate social responsibility, maka dengan demikian $\mathrm{H}_{1}$ ditolak.

\section{Pengaruh Profitabilitas terhadap Corporate Social Responsibility}

Berdasarkan tabel diatas diketahui bahwa variabel profitabilitasmemiliki nilai $t_{\text {hitung }}$ $>t_{\text {tabel }}(2,358>1,99085)$ dan nilai sig sebesar $0,014<0,05$ berarti variabel profitabilitas 
berpengaruh positif terhadap corporate social responsibility, maka dengan demikian $\mathrm{H}_{2}$ diterima.

\section{Pengaruh Leverage terhadap Corporate Social Responsibility}

Berdasarkan tabel diatas diketahui bahwa variabel leverage memiliki nilai $t_{\text {hitung }}>\mathrm{t}_{\text {tabel }}$ $(3,628>1,99085)$ dan nilai sig sebesar $0,000<0,05$ berarti variabel leverage berpengaruh positif terhadap corporate social responsibility, maka dengan demikian $\mathrm{H}_{4}$ diterima.

\section{Pengaruh Kepemilikan Institusional terhadap Corporate Social Responsibility}

Berdasarkan tabel diatas diketahui bahwa variabel regulasi pemerintahmemiliki nilai $t_{\text {hitung }}>\mathrm{t}_{\text {tabel }}(2,445>1,99085)$ dan nilai sig sebesar $0,016<0,05$ berarti variabel kepemilikan institusional berpengaruh positif terhadap corporate social responsibility, maka dengan demikian $\mathrm{H}_{6}$ diterima.

\section{Pengaruh Kepemilikan Asing terhadap Corporate Social Responsibility}

Berdasarkan tabel diatas diketahui bahwa variabel kepemilikan asing memiliki nilai $\mathrm{t}_{\text {hitung }}<\mathrm{t}_{\text {tabel }}(1,276<1,99085)$ dan nilai sig sebesar $0,176>0,05$ berarti variabel kepemilikan asing tidak berpengaruh terhadap corporate social responsibility, maka dengan demikian $\mathrm{H}_{7}$ ditolak.

\section{KESIMPULAN}

Berdasarkan data yang diperoleh dan dari hasil analisis data yang dilakukan maka diperoleh beberapa kesimpulan sebagai berikut :

1. Regulasi pemerintah tidak berpengaruh terhadap pengungkapan corporate social responsibility. Dalam hal ini perusahaan yang menerapkan peraturan pemerintah dengan baik tidak mempengaruhi pengungkapan corporate social responsibilty, karena peraturan pemerintah belum tentu sesuai dengan kondisi dan kebijakan perusahaan.

2. Profitabilitas berpengaruh positif terhadap pengungkapan corporate social responsibility. Hal ini berarti bahwa semakin tinggi laba yang dihasilkan perusahaan, maka semakin tinggi pengungkapan corporate social responsibility, karena dengan peningkatan laba perusahaan akan lebih transparan dalam pengungkapan corporate social responsibility

3. Leverage berpengaruh positif terhadap pengungkapan corporate social responsibility. Hal ini berarti bahwa semakin tinggi kemampuan perusahaan mengelola hutang akan meningkatkan pengungkapan corporate social responsibility, karena investasi dengan hutang yang efisien dan efektif perlu diungkapkan untuk meningkatkan nilai perusahaan. 
4. Kepemilikan institusional berpengaruh positif pengungkapan corporate social responsibility. Hal ini berarti bahwa semakin tinggi saham yang dimiliki institusional akan meningkatkan pengungkapan corporate social responsibility, karena pihak institusi memotivasi perusahaan untuk lebih transparan dalam mengungkapkan aktivitas perusahaan.

5. Kepemilikan asing tidak berpengaruh terhadap pengungkapan corporate social responsibility. Dalam hal ini saham asing yang terdapat dalam perusahaan tidak mempengaruhi pengungkapan corporate social responsibility, karena pihak asing tidak memiliki hak mayoritas dalam pengambilan keputusan dan kebijakan perusahaan.

\section{Keterbatasan}

1. Variabel independen pengaruh regulasi pemerintah, profitabilitas, kepemilikan institusional, kepemilikan asing mampu menjelaskan 46,7\% variasi besarnya corporate social responsibility (CSR) sedangkan sisanya 53,3\% dijelaskan oleh variabel lain, sehingga diperlukan variabel lain yang kemungkinan dapat berpengaruh terhadap corporate social responsibility (CSR).

2. Fokus penelitian ini hanya pada perusahaan manufaktur yang terdaftar di Bursa Efek Indonesia periode 2013-2016 sehingga tidak dapat menggambarkan hasil data secara jelas berkaitan dengan pengungkapan corporate social responsibility.

\section{Saran}

Berdasarkan hasil dan keterbatasan penelitian yang telah diuraikan diatas maka dapat diberikan saran sebagai berikut ::

1. Penambahan variabel bebas lainnya yang berpengaruh terhadap corporate social responsibility seperti ukuran dewan komisaris, karena perusahaan yang memiliki struktur dewan komisaris yang baik dapat meningkatkan tanggung jawab sosial perusahaan kepada lingkungan perusahaan sehingga dapat meningkatkan nilai perusahaansesuai dengan penelitian Hafriyanti (2016).

2. Diharapkan peneliti selanjutnya memperpanjang periode penelitian dan memperluas obyek penelitian berkaitan dengan perusahaan-perusahaan yang memiliki pengungkapan corporate social responsibility.

\section{DAFTAR PUSATAKA}


Agustia,Dian. 2013.Pengaruh Struktur Kepemilikan Dan Dewan Komisaris Terhadap Corporate Social Responsibility Dan Reaksi Pasar. Ekuitas: Jurnal Ekonomi dan Keuangan - Volume 17, Nomor 3, September 2013 : 376 - 390.

Astuti,Fitria Puji dkk. 2014.Pengaruh Kinerja Lingkungan Dan Kepemilikan Asing Terhadap Kinerja Keuangan.Fitria Puji Astuti / Accounting Analysis Journal 3 (4) (2014).

Astuti, Rachmawati Nur Puji, dan Rina Trisnawati. 2015.Pengaruh Karakteristik Perusahaan Manufaktur TerhadapPengungkapan Corporte Social Responsibility (CSR) Serta Dampaknya Terhadap Reaksi Investor ( Studi Pada Perusahaan Manufaktur di Bursa Efek Indonesia Periode Tahun 2010-2013 ).ISSN 2460-0784 Seminar Nasional dan The 2nd Call for Syariah Paper.

Bursa Efek Indonesia, 2017.www.bursa efek Indonesia.com

Dewi,Ni Putu Marni Sepian dan I G. N. Agung Suaryana. 2015.Pengaruh Profitabillitas Dan Kepemilikan Asing Pada Pengungkapan Corporate Social Responsibility.E-Jurnal Akuntansi Universitas Udayana 13.1 (2015):

Ghozali, Imam dan Anis Chariri, 2007. Teori akuntansi edisi 3.Semarang: universitas diponegoro ISBN: 979.704.014.3

Ghozali, Imam. 2016. Aplikasi Analisis Multivariate dengan Program IBM SPSS 21. Semarang :Universitas Diponegoro

Hadi, Nur. 2011. Corporate Social Responsibility. Semarang

Herawati,Heti. 2015.Corporate Governance, Karakteristik Perusahaan dan Pengungkapan Corporate social responsibility. Jurnal Riset Akuntansi dan Perpajakan JRAP Vol. 2, No. 2, Desember 2015, hal203 - 217 .ISSN 2339 - 1545.

Indraswari,Gusti Ayu Dyah Dan Ida Bagus Putra Astika. 2014. Pengaruh Profitabilitas, Ukuran Perusahaan, Dan Kepemilikan Saham Publik Pada Pengungkapan CSR.EJurnal Akuntansi Universitas Udayana 9.3 (2014)

Indraswari, Gusti Dyah Ayu Dan Ida Bagus Putra Astika 2015,Pengaruh Profitabilitas, Ukuran Perusahaan, Dan Kepemilikan Saham Publik Terhadap Pengungkapan CSR.E-Jurnal Akuntansi Universitas Udayana 11.1 (2015).

Kuncoro, Mudrajad. 2009. Metode Riset untuk Bisnis dan Ekonomi edisi 3. Penerbit Erlangga

Miftah,Desrir dan Zainal Arifin. 2013.Analisis Pengaruh Ukuran Perusahaan, Profitabilitas, Leverage Dan Ukuran Dewan Komisaris Terhadap Pengungkapan Tanggung jawab Sosial Perusahaan (Corporate Social Responsibility)Jurnal AlIqtishad, Vol. 9 No 1 Tahun 2013.

Munsaidah, Siti, Rita Andini, dan Agus Supriyanto. 2016.Analisis Pengaruh Firm Size, Age, Profitabilitas, Leverage, Dan Growth Perusahaan Terhadap Corporate Social Responsibility (CSR) Pada Perusahaan Property Dan Real Estate Yang Terdaftar Di Bursa Efek Indonesia Pada Tahun 2010-2014. Journal Of Accounting, Volume 2 No.2 Maret 2016. 
Mutia,Evi.dkk. 2011.Pengaruh Ukuran Perusahaan, Profitabilitas Dan Ukuran Dewan Komisaris Terhadap Pengungkapan Corporate Social Responsibility Pada Perusahaan Manufaktur Yang Terdaftar Di Bursa Efek Indonesia. Jurnal Telaah\& Riset Akuntansi .Vol. 4. No. 2. Juli 2011.

Oktariani, Wulantika. 2013.Pengaruh Kepemilikan Publik, Ukuran Dewan Komisaris, Profitabilitas Dan Umur Persahaan Terhadap PengungkapanTanggung Jawab Sosial Perusahaan.Jurnal Ilmiah Wahana Akuntansi Volume 8, No.2, Tahun 2013.

Pradnyani,I Gusti Agung Arista dan Eka Ardhani Sisdyani. 2015.Pengaruh Ukuran Perusahaan, Profitabilitas, Leverage, Dan Ukuran Dewan Komisaris Pada Pengungkapan Tanggung Jawab Sosial Perusahaan. E-Jurnal Akuntasi Universitas Udayana 11.2 (2015).

Rahayu,Puji dan Indah Anisyukurlillah. 2015.Pengaruh Kepemilikan Saham Publik, Profitabilitas Dan Media Terhadap Pengungkapan Tanggung Jawab Sosial.2015 Universitas Negeri Semarang Alamat korespondensi: Gedung C6 Lantai 2 FE Unnes Kampus Sekaran, Gunungpati, Semarang, 50229 E-mail:zizi_lea@yahoo.com ISSN 2252-6765.

Rahmayanty,Sri.2015.Pengaruh Size Perusahaan, Kepemilikan Saham Publik, Kepemilikan Saham Asing, Dan Profitabilitas Perusahaan Terhadap Pengungkapan Corporate Social Responsibility (CSR) Pada Perusahaan Food And Beverages Yang Terdaftar Di BEI Pada Tahun 2010-2013.Jom FEKON Vol. 2 No. 2 Oktober 2015.

Rindawati, Meita Wahyu Dan Nur Fadjrih Asyik. 2015 .Pengaruh Profitabilitas, Ukuran Perusahaan, Leverage, Dan Kepemilikan Publik Terhadap Pengungkapan Corporate Social Responsibility (CSR).Sekolah Tinggi Ilmu Ekonomi Indonesia (STIESIA) Surabaya.

Rustiarini,Ni Wayan. 2011.Pengaruh Struktur Kepemilikan Saham Pada Pengungkapan Corporate Social Responsibility.Jurusan Akuntansi Fakultas Ekonomi, Universitas Mahasaraswati Denpasar.

Siti Munsaidah, dkk. 2016.Analisis Pengaruh Firm Size, Age, Profitabilitas, Leverage, Dan Growth Perusahaan Terhadap Corporate Social Responsibility (CSR) Pada Perusahaan Property Dan Real Estate Yang Terdaftar Di Bursa Efek indonesia Pada Tahun 2010-2014.Journal Of Accounting, Volume 2 No.2 Maret 2016.

Sriayu,Gusti Ayu Putu Wiwik dan Ni Putu Sri Harta Mimba. 2013.Pengaruh Karakteristik Perusahaan Terhadap Corporate Social Responsibility Disclosure.E-Jurnal Akuntansi Universitas Udayana 5.2 (2013)

Sugiyono, 2014. Statistika Untuk Penelitian. Bandung : CV.Alfabeta 